\title{
Enantiopure fluorous 1,2-diaryl-1,2-diaminoethanes: synthesis and applications in asymmetric organometallic catalysis
}

\author{
Jérome Bayardon and Denis Sinou* \\ Laboratoire de Synthèse Asymétrique associé au CNRS, UMR 5246-ICBMS, CPE Lyon, \\ Université Claude Bernard Lyon 1, 43, boulevard du 11 novembre 1918, 69622 Villeurbanne \\ cédex, France \\ E-mail: sinou@univ-lyon1.fr
}

Dedicated to Professor Guy Quéguiner on his 70th birthday

\begin{abstract}
The synthesis of a new enantiopure fluorous 1,2-diaryl-1,2-diaminoethane bearing two fluorous ponytails is described. The palladium-catalyzed reaction of 1,3-diphenyl-2-propenyl acetate with dimethyl malonate in the presence of this ligand and its analogue bearing four fluorous ponytails gave the alkylated product with ee up to 44\%. Their application as ligands in hydrogen transfer reactions associated with rhodium, iridium, or ruthenium in a two-phase system gave ee up to $39 \%$, the catalyst being recycled without loss of enantioselectivity in the case of the ruthenium complex.
\end{abstract}

Keywords: Enantiopure fluorous diamines, asymmetric catalysis, allylic alkylation, hydrogentransfer reaction

\section{Introduction}

Enantiopure 1,2-diamines, particularly those possessing $C_{2}$-symmetry, and their derivatives, have found wide applications as chiral auxiliaries and ligands in asymmetric synthesis. ${ }^{1,2}$ Among the large variety of 1,2-diamine structures that have been synthesized and used as ligands in asymmetric catalysis, enantiomerically pure 1,2-diaryl-1,2-ethanediamines and their derivatives seem to be among the most studied, giving high enantioselectivities in a large number of metalcatalyzed enantioselective reactions. Intensive research has been devoted to the synthesis of such easily recoverable enantiopure 1,2-diaryl-1,2-ethanediamines. The hydrosolubilization of such ligands has been performed by attachment on the aromatic rings of hydrophilic substituents, such as phenolic hydroxy groups, ${ }^{3}$ polyethylene glycol chains, ${ }^{3,4}$ sulfonic acid ${ }^{5}$ or phosphonic acid ${ }^{6}$ functions. Heterogenization of these enantiopure diamines has also been performed by 
attachment to soluble or insoluble organic polymers, ${ }^{4,7}$ or immobilization onto inorganic supports. ${ }^{8}$ Fluorous techniques have recently been introduced in asymmetric synthesis and are rapidly emerging as convenient alternatives for the recovery of chiral catalysts. ${ }^{9}$

Our group has recently described the synthesis of some enantiopure fluorous 1,2-diamines and diimines, and described their use as ligands in metal-catalyzed asymmetric transfer hydrogenation of ketones using the FBS (Fluorous Biphasic System) concept. ${ }^{10}$ We also described the preparation of a fluorous 1,2-diphenyl-1,2-ethanediamine bearing four fluorous ponytails. ${ }^{11}$ Herein we report the synthesis of a new fluorous 1,2-diphenyl-1,2-ethanediamine bearing only two fluorous ponytails, and the application of these two fluorous ligands in asymmetric transfer hydrogenation and asymmetric allylic alkylation.

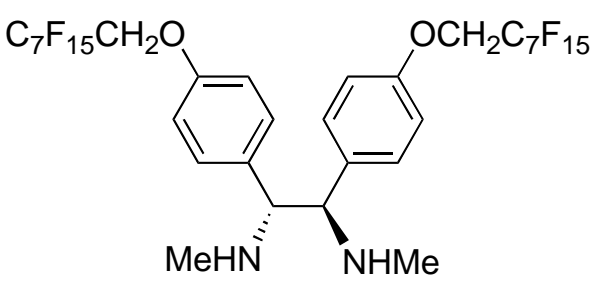

$(R, R)-1 \mathbf{a}$

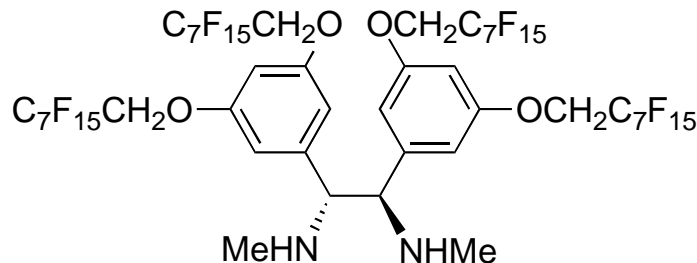

$(R, R)-\mathbf{1 b}$

Figure 1

\section{Results and Discussion}

The synthesis of the fluorous enantiopure diamine $\mathbf{1 b}$ has already been described by our group. ${ }^{11}$

The preparation of the enantiopure fluorous 1,2-diphenyl-1,2-diamine 1a is shown in Scheme 1. Racemic ( $\left.1 R^{*}, 2 R^{*}\right)$-1,2-bis-(4-methoxyphenyl)ethane-1,2-diamine (4) was prepared according to Corey's procedure. ${ }^{12}$ Refluxing commercial 4,4'-dimethoxybenzil (2) in acetic acid with 1 equivalent of cyclohexanone and ammonium acetate afforded the diimine 3 in $91 \%$ yield. Reduction of this diimine 3 with lithium (4 equiv.) in a mixture of $\mathrm{NH}_{3} / \mathrm{THF}$ (5:4) at $-78{ }^{\circ} \mathrm{C}$, followed by acidic hydrolysis using aqueous $\mathrm{HCl}$, gave stereoselectively the racemic primary diamine 4 in 89\% yield. Reaction of this racemic diamine 4 with (-)-menthyl chloroformate in the presence of pyridine, according to Denmark's procedure ${ }^{13}$ gave the corresponding bis(menthyl carbamate) diastereoisomers $(1 R, 2 R)-5 \mathbf{a}$ and $(1 S, 2 S)-5 \mathbf{b}$. Separation of these two diastereoisomers was performed by column chromatography, affording pure $\mathbf{5 a}$ and $\mathbf{5 b}$ in 32 and $19 \%$ yields, respectively. The absolute configuration of the diamine moiety of the two

diastereoisomers $\mathbf{5 a}$ and $\mathbf{5 b}$ was deduced by comparison of their ${ }^{1} \mathrm{H}$ NMR spectra and their relative polarity on TLC with those described in the literature. ${ }^{13}$ 
<smiles>COc1ccc(C(=O)C(=O)c2ccc(OC)cc2)cc1</smiles>

2

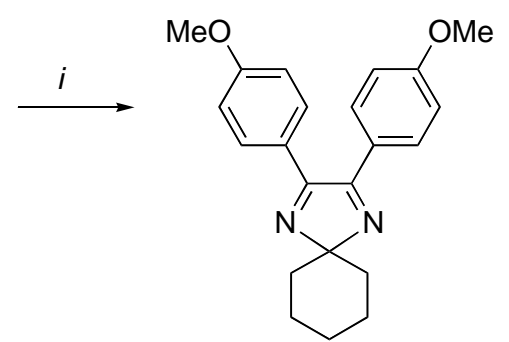

3

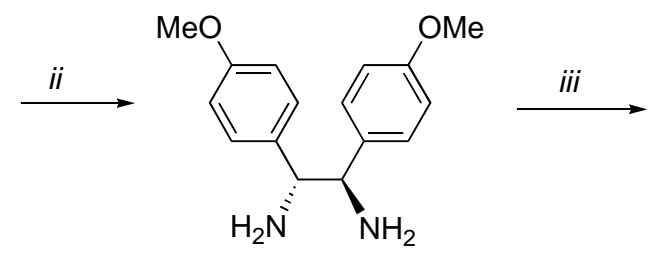

$( \pm)-4$

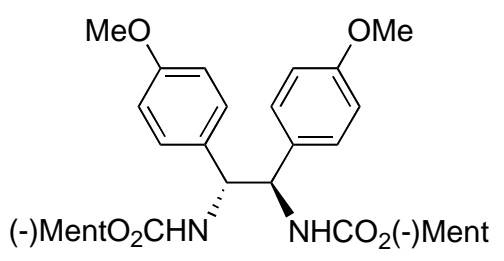

$(R, R)-5 \mathbf{a}$

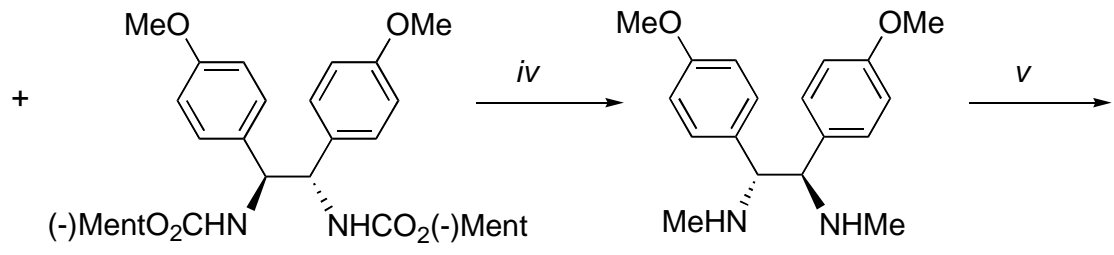

$(S, S)-5 b$

$(R, R)-6$

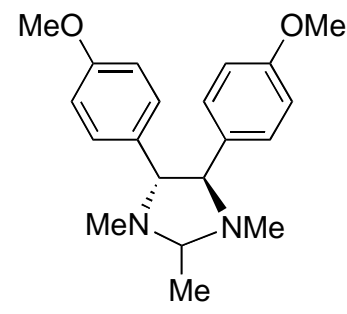

$(R, R)-7$

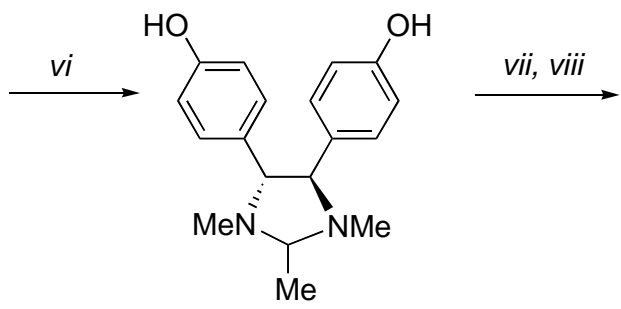

$(R, R)-8$

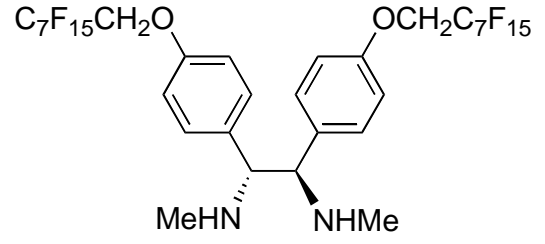

$(R, R)-1 \mathbf{a}$

Scheme 1. Reagents and conditions: (i) cyclohexanone, $\mathrm{NH}_{4} \mathrm{OAc}, \mathrm{AcOH}$; (ii) Li, THF/NH $3,-78$ ${ }^{\circ} \mathrm{C}$, then $\mathrm{H}_{3} \mathrm{O}^{+}$; (iii) (-)-MenthOCOCl, $\mathrm{C}_{5} \mathrm{H}_{5} \mathrm{~N}, \mathrm{CH}_{2} \mathrm{Cl}_{2}$; (iv) separation by column chromatography, then $\mathrm{LiAlH}_{4}$ for $(R, R)-5 \mathbf{b}$, DME; (v) MeCHO, molecular sieves; (vi) $\mathrm{BBr}_{3}$, $\mathrm{CH}_{2} \mathrm{Cl}_{2},{ }^{\circ} \mathrm{C}$; (vii) $\mathrm{C}_{7} \mathrm{~F}_{15} \mathrm{CH}_{2} \mathrm{OSO}_{2} \mathrm{C}_{4} \mathrm{~F}_{9}, \mathrm{CsCO}_{3}$, DMF, $80{ }^{\circ} \mathrm{C}$; (viii) $\mathrm{H}_{3} \mathrm{O}^{+}$.

$(1 R, 2 R)$-1,2-Bis-(4-methoxyphenyl)- $N, N^{\prime}$-dimethylethane-1,2-diamine (6) was obtained in $66 \%$ chemical yield by reduction of the diastereoisomer $(1 R, 2 R)-5$ a with $\mathrm{LiAlH}_{4}$ in anhydrous DME. This enantiopure diamine 6 was transformed into (4R,5R)-4,5-bis-(4-methoxyphenyl)1,2,3-trimethylimidazolidine (7) in $90 \%$ yield by condensation with acetaldehyde in the presence of $4 \AA$ molecular sieve as $\mathrm{H}_{2} \mathrm{O}$ scavenger. Cleavage of the two methoxy groups of compound 7 by $\mathrm{BBr}_{3}$ in dichloromethane afforded the corresponding dihydroxy amine $\mathbf{8}$ in $90 \%$ yield. This protected diamine 8 was reacted with $1 \mathrm{H}, 1 \mathrm{H}$-perfluorooctan-1-yl nonafluorobutanesulfonate in the presence of $\mathrm{CsCO}_{3}$ in $\mathrm{DMF}$ allowing the introduction of two fluorous ponytails into this compound. Acidic treatment of the latter fluorous compound gave the fluorous $(1 R, 2 R)-1,2-$ diaryl- $N, N$ '-dimethylethanediamine 1a in a 38\% yield overall.

In order to use these two substrates as ligands in asymmetric organometallic catalysis we measured their equilibrium distribution between FC-72, a fluorous solvent, and various non- 
fluorous solvents (Table 1). As expected, the fluorous diamine 1a, bearing two fluorous ponytails and with a fluorous content of $55 \%$, is preferentially dissolved in the non-fluorous solvent, whatever the latter. Conversely, the fluorous diamine $\mathbf{1 b}$, bearing four fluorous ponytails and a fluorous content of $62.2 \%$, exhibited very good fluorophilicity, with partition coefficients of 10.36 and 2.23, respectively in the presence of acetonitrile or ethanol, allowing its probable use as a ligand in a two-phase system of fluorous solvent-non-fluorous solvent.

Table 1. Partition coefficients $P$ ( $\left.P=c_{\text {fluorous phase }} / c_{\text {organic solvent }}\right)$ for fluorous diamines 1 a-b between FC-72 and standard organic solvents ${ }^{\mathrm{a}}$

\begin{tabular}{cccccccc}
\hline \multirow{2}{*}{ Diamine } & \multirow{2}{*}{$\% \mathrm{~F}$} & \multicolumn{2}{c}{ Toluene/FC-72 } & \multicolumn{2}{c}{$\mathrm{CH}_{3} \mathrm{CN} / \mathrm{FC}-72$} & \multicolumn{3}{c}{$\mathrm{C}_{2} \mathrm{H}_{5} \mathrm{OH} / \mathrm{FC}-72$} \\
\cline { 3 - 8 } & & $\% v / v$ & $P$ & $\% v / v$ & $P$ & $\% v / v$ & $P$ \\
\hline 1a & 55.0 & $82.8 / 17.2$ & 0.21 & $74.0 / 26.0$ & 0.35 & $90.0 / 10.0$ & 0.11 \\
1b & 62.2 & $16.0 / 84.0$ & 5.25 & $8.8 / 91.2$ & 10.36 & $31.0 / 69.0$ & 2.23 \\
\hline
\end{tabular}

${ }^{a}$ In a 50:50 (v:v) mixture of FC-72/organic solvent at $25{ }^{\circ} \mathrm{C}$. Determined gravimetrically (see Experimental Section).

The fluorous diamines 1a,b were tested as ligands in the allylic alkylation of 1,3-diphenyl-2propenyl acetate with dimethyl malonate catalyzed by $\operatorname{Pd}(0)$ (Tsuji-Trost alkylation). This reaction was first done at room temperature in THF, using the fluorous ligand $\mathbf{1}$ (6 mol.\%) and $\left[\mathrm{Pd}\left(\eta^{3}-\mathrm{C}_{3} \mathrm{H}_{5}\right) \mathrm{Cl}\right]_{2}(2.5 \mathrm{~mol} . \%)$ in the presence of $\mathrm{NaH}$ as the base. The alkylated product was obtained in $28 \%$ and 32\%, after two days, using ligands $\mathbf{1 a}$ and $\mathbf{1 b}$, respectively, with 28 and $32 \%$ ee (Table 2, entries 1 and 2). However, performing this reaction at $50{ }^{\circ} \mathrm{C}$ afforded quantitatively the coupling product with 29 and 35\% ee, respectively (Table 2, entries 2 and 4). All attempts to perform this alkylation reaction in a two-phase system of fluorous solvent/nonfluorous solvent failed.

Table 2. Enantioselective allylic alkylation of 1,3-diphenyl-2-propenyl acetate using fluorous diamines $\mathbf{1}^{\text {a }}$

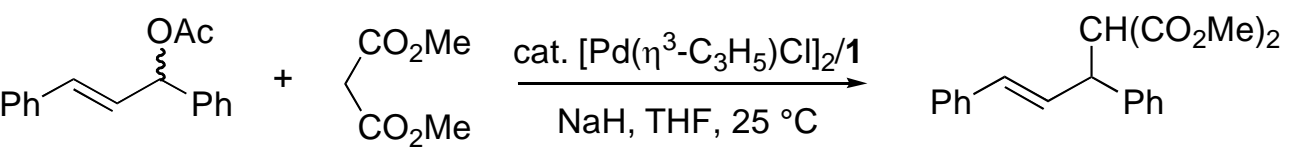

\begin{tabular}{lccccc}
\hline Entry & Ligand & Temp $\left({ }^{\circ} \mathrm{C}\right)$ & Time $(\mathrm{h})$ & Conv. (\%) & ee (\%) Config. \\
\hline 1 & 1a & 25 & 48 & 28 & $32(R)$ \\
2 & 1a & 50 & 24 & 99 & $29(R)$ \\
3 & 1b & 25 & 48 & 32 & $44(R)$ \\
4 & 1b & 50 & 24 & 98 & $35(R)$ \\
\hline
\end{tabular}

${ }^{a}$ Diamine $\mathbf{1}=6$ mol. \%; $\left[\mathrm{Pd}\left(\eta^{3}-\mathrm{C}_{3} \mathrm{H}_{5}\right) \mathrm{Cl}\right]_{2}=2.5 \mathrm{~mol}$ \%; conversion and ee determined by GC and HPLC, respectively (see Experimental Section for details). 
We next turned our attention to the catalytic hydrogen-transfer reduction. These fluorous diamines 1a-b, in association with $\left[\mathrm{Rh}\left(\mathrm{C}_{6} \mathrm{H}_{10}\right) \mathrm{Cl}\right]_{2}$ were successfully tested in the asymmetric reduction of acetophenone with isopropanol as the hydride source in the presence of PFMCH as the fluorous solvent at $70{ }^{\circ} \mathrm{C}$ (Table 3, entry 1 and 2). The reduction was almost quantitative after one hour using the two ligands, with ee up to $35 \%$ in the presence of ligand $\mathbf{1 b}$. Since only ligand $\mathbf{1 b}$ could allow the recycling of the catalyst, all the following experiments were performed in the presence of $\mathbf{1 b}$. It is to be noted that the recycling of the catalyst $\left[\mathrm{Rh}\left(\mathrm{C}_{6} \mathrm{H}_{10}\right) \mathrm{Cl}\right]_{2} /$ ligand $\mathbf{1 b}$ gave also a quantitative conversion after one hour, but with a lower enantioselectivity (22\% ee) (Table 3, entry $2 *$ ).

The catalyst obtained by mixing $[\operatorname{Ir}(\mathrm{COD}) \mathrm{Cl}]_{2}$ and ligand $\mathbf{1 b}$ afforded quantitatively the alcohol after one hour with ee up to 28 . The recycling of this catalyst was also possible with the same activity; unfortunately the enantioselectivity dropped to 7\% (Table 3, entries 3 and $3 *$ ).

Finally the complex $[\mathrm{Ru}(p$-cymene $)) \mathrm{Cl}]_{2}$ associated with diamine $\mathbf{1 b}$ gave quantitatively the reduced product after three hours, with 33\% ee; this catalyst allowed efficient recycling, 39\% ee being obtained in this case (Table 3 , entries 4 and $4 *$ ).

Table 3. Catalytic hydrogen transfer reduction of acetophenone using fluorous chiral diamines $\mathbf{1}^{\mathrm{a}}$

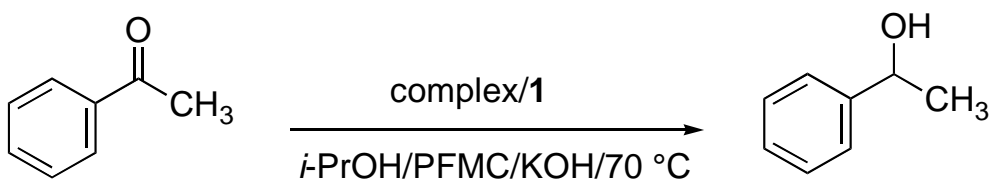

\begin{tabular}{lclccc}
\hline Entry & Ligand & Complex & Time $(\mathrm{h})$ & Conv. (\%) & ee (\%) Config. \\
\hline 1 & 1a & {$\left[\mathrm{Rh}\left(\mathrm{C}_{6} \mathrm{H}_{10}\right) \mathrm{Cl}\right]_{2}$} & 1 & 99 & $26(S)$ \\
2 & $\mathbf{1 b}$ & {$\left[\mathrm{Rh}\left(\mathrm{C}_{6} \mathrm{H}_{10}\right) \mathrm{Cl}\right]_{2}$} & 1 & 98 & $35(S)$ \\
$2^{*, \mathrm{~b}}$ & $\mathbf{1 b}$ & {$\left[\mathrm{Rh}\left(\mathrm{C}_{6} \mathrm{H}_{10}\right) \mathrm{Cl}\right]_{2}$} & 1 & 98 & $22(S)$ \\
3 & $\mathbf{1 b}$ & {$[\operatorname{Ir}(\mathrm{COD}) \mathrm{Cl}]_{2}$} & 1 & 99 & $28(S)$ \\
$3^{*, \mathrm{~b}}$ & $\mathbf{1 b}$ & {$[\operatorname{Ir}(\mathrm{COD}) \mathrm{Cl}]_{2}$} & 1 & 98 & $7(S)$ \\
4 & $\mathbf{1 b}$ & {$[\mathrm{Ru}(p \text {-cymene }) \mathrm{Cl}]_{2}$} & 3 & 98 & $33(S)$ \\
$4^{*, \mathrm{~b}}$ & $\mathbf{1 b}$ & {$[\mathrm{Ru}(p \text {-cymene }) \mathrm{Cl}]_{2}$} & 4 & 97 & $39(S)$ \\
\hline
\end{tabular}

${ }^{\mathrm{a}}$ Diamine $=10 \mathrm{~mol} . \%$; complex $=5 \mathrm{~mol} \%$; $\mathrm{PFMCH} / \mathrm{i}-\mathrm{PrOH}=1: 1 \mathrm{v} / \mathrm{v}$; conversion and ee determined by GC (see Experimental Section for details). ${ }^{b}$ With recycling of the catalyst.

\section{Conclusions}

We describe here a quite general approach for the synthesis of enantiopure fluorous 1,2-diaryl1,2-diaminoethanes, bearing some fluorous ponytails. These fluorous ligands have been used as ligands in the palladium-catalyzed alkylation of 1,3-diphenyl-2-propenyl acetate with dimethyl malonate in tetrahydrofuran as the solvent, with ee up to $44 \%$ being obtained. These fluorous 
diamines have also been used in the reduction of acetophenone by hydrogen transfer associated with rhodium, iridium, or ruthenium complexes, with ee in the range of $26-35 \%$. The use of a biphasic system $i-\mathrm{PrOH}$-fluorous solvent allows recycling of the catalyst, with no decrease in enantioselectivity in the case of the ruthenium catalyst.

\section{Experimental Section}

General Procedures. Solvents were purified by standard methods and dried if necessary, except for perfluoromethylcyclohexane (PFMC), which was used as received. FC-72 (mixture of fluorous hexanes) and 4,4'-dimethoxybenzil (2) were commercially available, $1 \mathrm{H}, 1 \mathrm{H}$ perfluorooctan-1-yl nonafluorobutanesulfonate was prepared according to the literature. ${ }^{14}$ Column chromatography was performed on silica gel 60 (230-240 mesh, Merck). Melting points (uncorrected) were determined with a Büchi SMP-20 capillary melting point apparatus. Optical rotations were recorded using a Perkin-Elmer 241 polarimeter. The NMR spectra $(1 \mathrm{H}-300$ $\mathrm{MHz},{ }^{13} \mathrm{C}-75.4 \mathrm{MHz},{ }^{19} \mathrm{~F}-282 \mathrm{MHz}$ ) were recorded on a Bruker AC $300 \mathrm{MHz}$ instrument with $\mathrm{Me}_{4} \mathrm{Si}, \mathrm{CDCl}_{3}$, and $\mathrm{CFCl}_{3}$, respectively, as the internal standards. Reactions involving organometallic catalysis were carried out in Schlenk tubes under an inert atmosphere. Absolute configurations of the enantiomers were determined by comparison of GC- and HPLC retention times with those of authentic samples.

2,3-Bis-(4-methoxyphenyl)-1,4-diazaspiro[4.5]deca-1,3-diene (3). A mixture of 4,4'dimethoxybenzil 2 (4 g, $14.8 \mathrm{mmol}$ ), cyclohexanone (1.5 g, $15.2 \mathrm{mmol})$, and ammonium acetate $(7.87 \mathrm{~g}, 102.1 \mathrm{mmol})$ in glacial acetic acid $(40 \mathrm{~mL})$ was heated at reflux for $1.5 \mathrm{~h}$, and then poured into water $(50 \mathrm{~mL})$. The mixture was extracted with $\mathrm{CH}_{2} \mathrm{Cl}_{2}(3 \times 30 \mathrm{~mL})$. The combined organic phases were washed with a saturated aqueous solution of $\mathrm{NaHCO}_{3}(2 \times 30 \mathrm{~mL})$, and dried over $\mathrm{Na}_{2} \mathrm{SO}_{4}$. Evaporation of the solvent under reduced pressure gave a residue that was purified by column chromatography on silica gel [petroleum-EtOAc, 3:2 eluent] to afford the diimine 3 (4.69 g, 91\%) as a yellow solid; mp 96-98 ${ }^{\circ} \mathrm{C}$ (lit. ${ }^{15} \mathrm{mp} 109-110{ }^{\circ} \mathrm{C}$ ); $R_{f} 0.62$ (petroleumEtOAc, 3:2); ${ }^{1} \mathrm{H}$ NMR $\left(\mathrm{CDCl}_{3}\right) \delta 1.71-1.80\left(6 \mathrm{H}, \mathrm{m}, \mathrm{CH}_{2}\right), 1.95\left(4 \mathrm{H}, \mathrm{m}, \mathrm{CH}_{2}\right), 3.83(6 \mathrm{H}, \mathrm{s}$, $\left.\mathrm{OCH}_{3}\right), 6.86\left(4 \mathrm{H}, \mathrm{d}, J=8.7 \mathrm{~Hz}, \mathrm{H}_{\text {arom }}\right), 7.47$ (4 H, d, $\left.J=8.7 \mathrm{~Hz}, \mathrm{H}_{\text {arom }}\right)$.

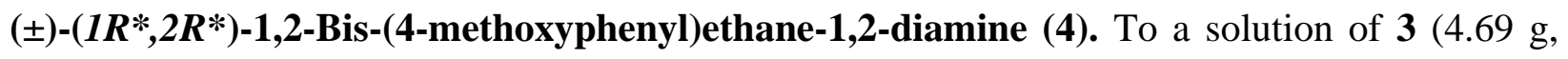
$13.5 \mathrm{mmol})$ in a $\mathrm{NH}_{3} / \mathrm{THF}$ mixture $(36 \mathrm{~mL}, 5: 4)$ at $-78{ }^{\circ} \mathrm{C}$ was slowly introduced $\mathrm{Li}(0.41 \mathrm{~g}$, $59.2 \mathrm{mmol}$ ). The solution was stirred at $-78{ }^{\circ} \mathrm{C}$ for $2 \mathrm{~h}$, during which additional amounts of EtOH were slowly added (1. $6 \mathrm{~mL}, 27 \mathrm{mmol})$. The mixture was stirred for an additional $30 \mathrm{~min}$ at $-78{ }^{\circ} \mathrm{C}$, and then treated with $\mathrm{NH}_{4} \mathrm{Cl}(3.76 \mathrm{~g}, 70 \mathrm{mmol})$. The mixture was allowed to warm to $0{ }^{\circ} \mathrm{C}$, water $(15 \mathrm{~mL})$ was carefully added, and the mixture was extracted with $\mathrm{Et}_{2} \mathrm{O}(3 \times 15 \mathrm{~mL})$. The combined organic phases were washed with brine $(20 \mathrm{~mL})$, dried $\left(\mathrm{Na}_{2} \mathrm{SO}_{4}\right)$, and concentrated under reduced pressure. The residue was treated with $\mathrm{Et}_{2} \mathrm{O}(20 \mathrm{~mL})$, and then with $2 \mathrm{M}$ aq. $\mathrm{HCl}(13 \mathrm{~mL})$ at $0{ }^{\circ} \mathrm{C}$. After stirring at RT for $1 \mathrm{~h}$, the obtained precipitate was filtered, the 
solid was washed with $\mathrm{Et}_{2} \mathrm{O}(3 \times 20 \mathrm{~mL})$, and then poured into $\mathrm{H}_{2} \mathrm{O}(20 \mathrm{~mL})$. A solution of aqueous $2 \mathrm{M} \mathrm{NaOH}(15 \mathrm{~mL})$ was added, the mixture extracted with $\mathrm{CH}_{2} \mathrm{Cl}_{2}(3 \times 30 \mathrm{~mL})$, and the combined organic phase dried $\left(\mathrm{Na}_{2} \mathrm{SO}_{4}\right)$. Evaporation of the solvent under reduced pressure gave the racemic diamine $4(3.26 \mathrm{~g}, 89 \%)$ as a yellow oil. ${ }^{1} \mathrm{H} \mathrm{NMR}\left(\mathrm{CDCl}_{3}\right) \delta 1.59\left(4 \mathrm{H}\right.$, br s, $\left.\mathrm{NH}_{2}\right)$, $3.80\left(6 \mathrm{H}, \mathrm{s}, \mathrm{OCH}_{3}\right), 4.03(2 \mathrm{H}, \mathrm{s}, \mathrm{CHN}), 6.82\left(4 \mathrm{H}, \mathrm{d}, J=8.6 \mathrm{~Hz}, \mathrm{H}_{\text {arom }}\right), 7.18(4 \mathrm{H}, \mathrm{d}, J=8.6$ $\left.\mathrm{Hz}, \mathrm{H}_{\text {arom }}\right)$ in agreement with the literature. ${ }^{15}$

Resolution of diamine (4) via bis-[(1R,2S,5R)-2-isopropyl-5-methylcyclohexyl][(1R,2R)-1,2bis-(4-methoxyphenyl)ethane-1,2-diyl]bis-carbamate (5). To a solution of racemic diamine 4 $(1.0 \mathrm{~g}, 3.67 \mathrm{mmol})$ and pyridine $(1.0 \mathrm{~mL}, 12.85 \mathrm{mmol})$ in anhydrous $\mathrm{CH}_{2} \mathrm{Cl}_{2}(15 \mathrm{~mL})$ at $0{ }^{\circ} \mathrm{C}$ was added (-)-menthyl chloroformate $(2.0 \mathrm{~mL}, 9.55 \mathrm{mmol})$. After being stirred at RT for $2 \mathrm{~h}$, the solvent was co-evaporated with toluene. The residue was purified by column chromatography on silica $\left[\mathrm{CH}_{2} \mathrm{Cl}_{2}\right.$-EtOAc (20:1) as eluent] to afford the less polar (1R,2R)-5a (740 $\mathrm{mg}, \mathbf{3 2 \%}$ ) and the more polar (1S,2S)-5b (435 mg, 19\%).

Bis-[(1R,2S,5R)-2-isopropyl-5-methylcyclohexyl][(1R,2R)-1,2-bis-(4-methoxyphenyl)ethane1,2-diyl]-bis-carbamate [(1R,2R)-5a]. Colorless solid; mp 236-238 ${ }^{\circ} \mathrm{C} ; R_{f}=0.68\left(\mathrm{CH}_{2} \mathrm{Cl}_{2}-\right.$ EtOAc, 30:1); $[\alpha]_{\mathrm{D}}{ }^{20}-65\left(c\right.$ 0.5, $\left.\mathrm{CHCl}_{3}\right) ;{ }^{1} \mathrm{H}$ NMR $\left(\mathrm{CDCl}_{3}\right) \delta 0.71\left(6 \mathrm{H}, \mathrm{d}, J=6.8 \mathrm{~Hz}, \mathrm{CH}_{3}\right)$, 0.84-2.10 (30 H, m, H $\left.\mathrm{H}_{\text {menthyl }}\right), 3.73$ (6 H, s, $\left.\mathrm{OCH}_{3}\right), 4.54$ (2 H, dt, $\left.J=10.9,4.4 \mathrm{~Hz}, \mathrm{CHO}\right), 4.89$ (2 H, m, CHN), 5.54 (2 H, br s, NH), $6.74\left(4 \mathrm{H}, \mathrm{d}, J=8.6 \mathrm{~Hz}, \mathrm{H}_{\text {arom }}\right), 6.99(4 \mathrm{H}, \mathrm{d}, J=8.6 \mathrm{~Hz}$, $\left.\mathrm{H}_{\text {arom }}\right)$ in agreement with the literature. ${ }^{13}$

Bis-[(1R,2S,5R)-2-isopropyl-5-methylcyclohexyl][(1S,2S)-1,2-bis-(4-methoxyphenyl)ethane1,2-diyl]bis-carbamate [(1S,2S)-5b]. Colorless oil; $\mathrm{R}_{f} 0.64\left(\mathrm{CH}_{2} \mathrm{Cl}_{2}-\mathrm{EtOAc}, 20: 1\right) ;{ }^{1} \mathrm{H}$ NMR $\left(\mathrm{CDCl}_{3}\right) \delta$ 0.85-1.92 (36 H, m, H $\mathrm{H}_{\text {menthyl) }}$ ) 3.75 (6 H, s, OCH $), 4.52$ (2 H, m, CHO), 4.84 (2 H, m, CHN), 5.57 (2 H, br s, NH), $6.73\left(4 \mathrm{H}, \mathrm{d}, J=8.1 \mathrm{~Hz}, \mathrm{H}_{\text {arom }}\right), 6.93\left(4 \mathrm{H}, \mathrm{d}, J=8.1 \mathrm{~Hz}, \mathrm{H}_{\text {arom }}\right)$ in agreement with the literature. ${ }^{13}$

$(1 R, 2 R)-1,2-B i s-(4-m e t h o x y p h e n y l)-N, N^{\prime}$-dimethylethane-1,2-diamine [1R,2R)-(6)]. To a solution of the bis-carbamate $(1 R, 2 R)-5(1.43 \mathrm{~g}, 2.26 \mathrm{mmol})$ in anhydrous DME $(60 \mathrm{~mL})$ maintained at $0{ }^{\circ} \mathrm{C}$ was added $\mathrm{LiAlH}_{4}(0.86 \mathrm{~g}, 22.6 \mathrm{mmol})$ in portions. The reaction mixture was heated at $85{ }^{\circ} \mathrm{C}$ for $20 \mathrm{~h}$, and the cooled to $0{ }^{\circ} \mathrm{C}$. Water $(4 \mathrm{~mL})$ was added slowly at $0{ }^{\circ} \mathrm{C}$, and then the mixture was heated at reflux for $30 \mathrm{~min}$. The mixture was cooled to RT, and the white precipitate filtered using a pad of Celite and washed with THF (3x20 mL). Evaporation of the solvent under reduced pressure gave a residue that was diluted with $\mathrm{Et}_{2} \mathrm{O}(20 \mathrm{~mL})$; a $1 M$ solution of gaseous $\mathrm{HCl}(3.7 \mathrm{~mL})$ in $\mathrm{Et}_{2} \mathrm{O}$ was then added. The mixture was stirred at $\mathrm{RT}$ for 10 min, and the solid obtained was filtered and washed with $\mathrm{Et}_{2} \mathrm{O}$. The solid was suspended in $\mathrm{Et}_{2} \mathrm{O}$ and treated with an aqueous $1 \% \mathrm{NaOH}$ solution until dissolution of the solid. The organic phase was separated, washed with $\mathrm{H}_{2} \mathrm{O}(2 \times 5 \mathrm{~mL})$, and dried $\left(\mathrm{Na}_{2} \mathrm{SO}_{4}\right)$. Evaporation of the solvent under reduced pressure gave the diamine 6 as a colorless solid (450 mg, 66\%), which was washed with hexane and dried. Mp $118-120^{\circ} \mathrm{C}$ (lit. $\left.{ }^{13} \mathrm{mp} 118-120{ }^{\circ} \mathrm{C}\right)$; $[\alpha]_{\mathrm{D}}{ }^{20}+36$ (c 0.9, $\left.\mathrm{CHCl}_{3}\right)\left(\right.$ lit. $^{13}[\alpha]_{\mathrm{D}}{ }^{20}$ +36.4 (c 1, $\left.\left.\left.\mathrm{CHCl}_{3}\right)\right) ;{ }^{1} \mathrm{H} \mathrm{NMR}\left(\mathrm{CDCl}_{3}\right) \delta 1.79(2 \mathrm{H}, \mathrm{br} \mathrm{s}, \mathrm{NH})\right), 2.23\left(6 \mathrm{H}, \mathrm{s}, \mathrm{NCH}_{3}\right), 3.46(2 \mathrm{H}, \mathrm{s}$, CHN), $3.74\left(6 \mathrm{H}, \mathrm{s}, \mathrm{OCH}_{3}\right), 6.71\left(4 \mathrm{H}, \mathrm{d}, J=8.6 \mathrm{~Hz}, \mathrm{H}_{\text {arom }}\right), 6.93\left(4 \mathrm{H}, \mathrm{d}, J=8.6 \mathrm{~Hz}, \mathrm{H}_{\text {arom }}\right.$ ). 
(4R,5R)-4,5-Bis-(4-methoxyphenyl)-1,2,3-trimethylimidazolidine [(4R,5R)-7]. The diamine 6 (268 mg, $0.9 \mathrm{mmol}$ ) was dissolved in $\mathrm{Et}_{2} \mathrm{O}(10 \mathrm{~mL})$ containing $4 \AA$ molecular sieves (310 mg) under magnetic stirring. Acetaldehyde $(0.093 \mathrm{~mL}, 1.66 \mathrm{mmol})$ was then added and the mixture was stirred at RT for $1 \mathrm{~h}$, then diluted with $\mathrm{CH}_{2} \mathrm{Cl}_{2}(10 \mathrm{~mL})$. The molecular sieves were removed by filtration. Evaporation of the solvent and the excess acetaldehyde under reduced pressure gave a residue that was purified by column chromatography on silica $\left[\mathrm{CH}_{2} \mathrm{Cl}_{2}-\mathrm{MeOH}\right.$ (10:1)] to give compound 7 (263 mg, 90\%) as a colorless solid. Mp 88-90 ${ }^{\circ} \mathrm{C} ; R_{f}=0.56\left(\mathrm{CH}_{2} \mathrm{Cl}_{2}-\mathrm{CH}_{3} \mathrm{OH}, 9: 1\right)$; ${ }^{1} \mathrm{H}$ NMR $\left(\mathrm{CDCl}_{3}\right) \delta 1.31\left(3 \mathrm{H}, \mathrm{d}, J=5.8 \mathrm{~Hz}, \mathrm{CH}_{3}\right), 2.21\left(3 \mathrm{H}, \mathrm{s}, \mathrm{NCH}_{3}\right), 2.25\left(3 \mathrm{H}, \mathrm{s}, \mathrm{NCH}_{3}\right)$, 3.27 and 3.56 (each $1 \mathrm{H}, \mathrm{d}, J=8.7 \mathrm{~Hz}, \mathrm{CHN}), 3.77\left(6 \mathrm{H}, \mathrm{s}, \mathrm{OCH}_{3}\right), 3.84(1 \mathrm{H}, \mathrm{q}, J=5.8 \mathrm{~Hz}$, $\left.\mathrm{CHCH}_{3}\right), 6.77\left(4 \mathrm{H}, \mathrm{d}, J=8.6 \mathrm{~Hz}, \mathrm{H}_{\text {arom }}\right), 7.04\left(2 \mathrm{H}, \mathrm{d}, J=8.6 \mathrm{~Hz}, \mathrm{H}_{\text {arom }}\right), 7.09$ (2 H, d, $J=8.6$ $\left.\mathrm{Hz}, \mathrm{H}_{\text {arom}}\right)$.

(4R,5R)-4,5-Bis-(4-hydroxyphenyl)-1,2,3-trimethylimidazolidine [(4R,5R)-8]. A $1 M$ solution of $\mathrm{BBr}_{3}$ in $\mathrm{CH}_{2} \mathrm{Cl}_{2}$ ( $3.54 \mathrm{~mL}, 3.54 \mathrm{mmol}$ ) was added slowly at $0{ }^{\circ} \mathrm{C}$ to a solution of the acetaminal $(4 R, 5 R)-7$ (263 mg, $0.8 \mathrm{mmol})$ in $\mathrm{CH}_{2} \mathrm{Cl}_{2}(5 \mathrm{~mL})$. After stirring for $16 \mathrm{~h}$ at $\mathrm{RT}$, the mixture was hydrolyzed by treatment with aqueous $1 M \mathrm{NaOH}(12.5 \mathrm{~mL})$. The $\mathrm{CH}_{2} \mathrm{Cl}_{2}$ was evaporated under reduced pressure, the resulting mixture filtered through Celite, and the $\mathrm{pH}$ of the solution adjusted to 8.5 with $0.1 \mathrm{M}$ aq. $\mathrm{HCl}$. Diethyl ether $(10 \mathrm{~mL})$ was added, the organic layer was separated, and the aqueous layer extracted with $\mathrm{Et}_{2} \mathrm{O}(5 \times 10 \mathrm{~mL})$. The combined organic phases were washed with brine $(2 \times 10 \mathrm{~mL})$, and dried $\left(\mathrm{Na}_{2} \mathrm{SO}_{4}\right)$. Evaporation of the solvent under reduced pressure gave the acetaminal 7 (141 mg, 90\%) as a brown solid, that was directly used for the next step without further purification; mp $100-102{ }^{\circ} \mathrm{C} ; R_{f}=0.28\left(\mathrm{CH}_{2} \mathrm{Cl}_{2}-\right.$ $\left.\mathrm{CH}_{3} \mathrm{OH}, 9: 1\right) ;[\alpha]_{\mathrm{D}}{ }^{20}=+96.1\left(c 0.5, \mathrm{CH}_{3} \mathrm{OH}\right) ;{ }^{1} \mathrm{H} \mathrm{NMR}\left(\mathrm{CD}_{3} \mathrm{COCD}_{3}\right) \delta 1.28(3 \mathrm{H}, \mathrm{d}, J=5.8 \mathrm{~Hz}$, $\left.\mathrm{CH}_{3}\right), 2.18\left(3 \mathrm{H}, \mathrm{s}, \mathrm{NCH}_{3}\right), 2.20\left(3 \mathrm{H}, \mathrm{s}, \mathrm{NCH}_{3}\right), 3.20(1 \mathrm{H}, \mathrm{d}, J=8.3 \mathrm{~Hz}, \mathrm{CHN}), 3.49(1 \mathrm{H}, \mathrm{d}, J=$ $8.3 \mathrm{~Hz}, \mathrm{CHN}), 3.85\left(1 \mathrm{H}, \mathrm{q}, J=5.8 \mathrm{~Hz}, \mathrm{CHCH}_{3}\right), 6.71\left(4 \mathrm{H}, \mathrm{d}, J=8.5 \mathrm{~Hz}, \mathrm{H}_{\text {arom }}\right), 6.95(2 \mathrm{H}, \mathrm{d}, J$ $\left.=8.5 \mathrm{~Hz}, \mathrm{H}_{\text {arom }}\right), 6.99\left(2 \mathrm{H}, \mathrm{d}, J=8.5 \mathrm{~Hz}, \mathrm{H}_{\text {arom }}\right)$.

\section{$(1 R, 2 R)-N, N$ '-Dimethyl-1,2-bis-\{4-[(1H,1H-perfluorooctyl)oxy]phenyl\}ethane-1,2-diamine}

[(1R,2R)-1a]. A mixture of compound (1R,2R)-7 (142 mg, $0.48 \mathrm{mmol}), \mathrm{CsCO}_{3}$ (53 mg, 1.62 $\mathrm{mmol}$ ), and $\mathrm{C}_{7} \mathrm{~F}_{15} \mathrm{CH}_{2} \mathrm{OSO}_{2} \mathrm{C}_{4} \mathrm{~F}_{9}(842 \mathrm{mg}, 1.23 \mathrm{mmol}$ ), in anhydrous DMF (6 mL) was stirred at $80{ }^{\circ} \mathrm{C}$ for $18 \mathrm{~h}$. After cooling to RT, $\mathrm{H}_{2} \mathrm{O}(10 \mathrm{~mL})$ was added, and the mixture extracted with $\mathrm{Et}_{2} \mathrm{O}(3 \times 10 \mathrm{~mL})$. The combined organic phase was washed with brine $(10 \mathrm{~mL})$, and dried $\left(\mathrm{Na}_{2} \mathrm{SO}_{4}\right)$. Evaporation of the solvent under reduced pressure gave a residue, that was purified by column chromatography on silica [petroleum-EtOAc (1:2)] to give the corresponding protected fluorous compound (227 mg, 45\%), that was used directly for the next step. The product obtained was diluted with $\mathrm{Et}_{2} \mathrm{O}(5 \mathrm{~mL})$, and a $1 M$ solution of gaseous $\mathrm{HCl}$ in $\mathrm{Et}_{2} \mathrm{O}(0.9 \mathrm{~mL})$ was added at $0{ }^{\circ} \mathrm{C}$. After stirring for $1 \mathrm{~h}$ at RT, the solvent was evaporated under reduced pressure, and the solid filtered off, and washed with $\mathrm{Et}_{2} \mathrm{O}(3 \times 5 \mathrm{~mL})$. To this solid was added $\mathrm{Et}_{2} \mathrm{O}(5 \mathrm{~mL})$, followed by aq. $1 \% \mathrm{NaOH}$ solution until all the solid had dissolved. The organic phase was separated, washed with $\mathrm{H}_{2} \mathrm{O}(3 \times 5 \mathrm{~mL})$, and dried $\left(\mathrm{Na}_{2} \mathrm{SO}_{4}\right)$. Evaporation of the solvent under reduced pressure afforded the fluorous diamine $(1 R, 2 R)-8(186 \mathrm{mg}, 38 \%)$ as a brown oil; $[\alpha]_{\mathrm{D}}{ }^{20}$ $=+19\left(c 0.5, \mathrm{CHCl}_{3}\right) ;{ }^{1} \mathrm{H}$ NMR $\left(\mathrm{CDCl}_{3}\right) \delta 2.12(2 \mathrm{H}, \mathrm{br} \mathrm{s}, \mathrm{NH}), 2.24\left(6 \mathrm{H}, \mathrm{s}, \mathrm{NCH}_{3}\right), 3.45(2 \mathrm{H}$, 
s, >CH-N), $4.38\left(4 \mathrm{H}, \mathrm{t}, J=13.0 \mathrm{~Hz}, \mathrm{OCH}_{2}\right), 6.73\left(4 \mathrm{H}, \mathrm{d}, J=8.7 \mathrm{~Hz}, \mathrm{H}_{\text {arom }}\right), 6.93(4 \mathrm{H}, \mathrm{d}, J=$ 8.7 Hz, $\left.\mathrm{H}_{\text {arom }}\right) ;{ }^{13} \mathrm{C} \mathrm{NMR}\left(\mathrm{CDCl}_{3}\right) \delta 34.7,65.7$ (d, $\left.J=26.0 \mathrm{~Hz}\right), 70.9,114.8,129.5,135.4,156.7$; ${ }^{19} \mathrm{~F} \mathrm{NMR}\left(\mathrm{CDCl}_{3}\right) \delta-126 ; 6$ (4 F, m, $\left.\mathrm{CF}_{2}\right),-123.6$ (4 F, m, $\left.\mathrm{CF}_{2}\right),-123.2\left(4 \mathrm{~F}, \mathrm{~m}, \mathrm{CF}_{2}\right),-122.5$ (8 $\mathrm{F}, \mathrm{m}, \mathrm{CF}_{2}$ ), $-120.3\left(4 \mathrm{~F}, \mathrm{~m}, \mathrm{CF}_{2}\right),-81.4\left(6 \mathrm{~F}, \mathrm{t}, J=9.1 \mathrm{~Hz}, \mathrm{CF}_{3}\right)$. HRMS (ESI) Calcd for $\mathrm{C}_{32} \mathrm{H}_{22} \mathrm{~N}_{2} \mathrm{O}_{2} \mathrm{~F}_{30}\left([\mathrm{M}+\mathrm{H}]^{+}\right)$1037.1280. Found: 1037.1275 .

Determination of partition coefficients $\boldsymbol{P}$. A $10 \mathrm{~mL}$ vial equipped with a magnetic stirrer was charged with the fluorous diamine 1 (50 mg), PFMC (2 mL) and the organic solvent ( $2 \mathrm{~mL})$. The mixture was thermostatted at $25^{\circ} \mathrm{C}$ and stirred vigorously for $4 \mathrm{~h}$. A $1 \mathrm{~mL}$ sample was taken out of each phase, evaporated to dryness, and weighed on an analytical balance. The partition coefficient $P$ was determined as the ratio between the weight of the fluorous phase residue and the weight of the organic phase residue.

Alkylation of ( \pm )-1,3-diphenyl-2-propenyl acetate. The catalyst was prepared in a Schlenk tube by stirring $\left[\mathrm{Pd}\left(\eta^{3}-\mathrm{C}_{3} \mathrm{H}_{5}\right) \mathrm{Cl}\right]_{2}(45.6 \mathrm{mg}, 12.5 \mu \mathrm{mol})$ and the fluorinated diamine $(30 \mu \mathrm{mol})$ in degassed THF (1.5 mL) at R.T. for 1 h. 1,3-Diphenyl-2-propenyl acetate (126 mg, $0.5 \mathrm{mmol})$ dissolved in THF (1.5 mL) was added and the solution stirred for a further $20 \mathrm{~min}$, after which it was transferred under nitrogen into another Schlenk tube containing a solution of $\mathrm{NaH}$ (36 mg, $1.5 \mathrm{mmol}$ ) and dimethyl malonate (198 mg, $1.5 \mathrm{mmol}$ ) in THF (2 mL). The solution was stirred at the desired temperature for the time indicated in Table 2. The conversion was determined by GC using a Quadrex OV1 column (30 m x $0.25 \mathrm{~mm}$ ) and the enantioselectivity by HPLC on a chiral stationary phase (column: Chiralpak AD; eluent hexane/i-PrOH 60:40).

Hydrogen-transfer reduction of acetophenone. The catalyst was prepared in a Schlenk tube by stirring $\left[\mathrm{Rh}\left(\mathrm{C}_{6} \mathrm{H}_{10}\right) \mathrm{Cl}\right]_{2}(8.8 \mathrm{mg}, 20 \mu \mathrm{mol}),[\operatorname{Ir}(\mathrm{COD}) \mathrm{Cl}]_{2}(10.3 \mathrm{mg}, 20 \mu \mathrm{mol})$, or $[\mathrm{Ru}(p-$ cymene $\left.\mathrm{Cl}_{2}\right]_{2}(12.2 \mathrm{mg}, 20 \mu \mathrm{mol})$ and the fluorinated diamine 1 (40 $\left.\mu \mathrm{mol}\right)$ in degassed PFMC (5 $\mathrm{mL}$ ) at $70{ }^{\circ} \mathrm{C}$ for $3 \mathrm{~h}$. To this solution, cooled to RT, was added a solution of acetophenone (48 $\mathrm{mg}, 0.4 \mathrm{mmol})$ and $\mathrm{KOH}(5.6 \mathrm{mg}, 0.1 \mathrm{mmol})$ in $i-\mathrm{PrOH}(5 \mathrm{~mL})$. The mixture was stirred at 70 ${ }^{\circ} \mathrm{C}$. The conversion and enantiomeric excess were determined by GC analysis using a capillary Quadrex OV1 column (30 m x 0.25 mm) and a capillary Cyclodex- $\beta$ column (30 m x 0.25 mm), respectively.

\section{References}

1. Bennani, Y. L.; Hanessian, S. Chem. Rev. 1997, 97, 3161. (b) Lucet, D.; Le Gall, T.; Mioskowski, C. Angew. Chem., Int. Ed. 1998, 37, 2580. (c) Fache, F.; Schulz, E.; Tommasino, M.; Lemaire, M. Chem. Rev. 2000, 100, 2159.

2. Selected recent examples: (a) Alexakis, A.; Tomassini, A.; Andrey, O.; Bernardinelli, G. Eur. J. Org. Chem. 2005, 1332. (b) Xue, D.; Chen, Y.-C.; Cui, X.; Wang, Q.-W.; Zhu, J.; Deng, J.-G. J. Org. Chem. 2005, 70, 3584. (c) Zhang, H.-L.; Liu, H.; Cui, X.; Mi, A.-Q.; Jiang, Y.-Z.; Gong, L.-Z. Synlett 2005, 615. (d) Terakado, D.; Koutaka, H.; Oriyama, T. 
Tetrahedron: Asymmetry 2005, 16, 1157. (e) Cobb, A. J. A.; Marson, C. M. Tetrahedron 2005, 61, 1269.

3. Ferrand, A.; Bruno, M.; Tommasino, M. L.; Lemaire, M. Tetrahedron: Asymmetry 2002, 13, 1379.

4. Li, X.; Chen, W.; Hems, W.; King, F.; Xiao, J. Tetrahedron Lett. 2004, 45, 951.

5. Ma, Y.; Liu, H.; Chen, L.; Cui, X.; Zhu, J.; Deng, J. Org. Lett. 2003, 5, 2103. (b) Bubert, C.; Blacker, J.; Brown, S. M.; Crosby, J.; Fitzjohn, S.; Muxworthy, J. P.; Thorpe, T.; Williams, J. M. J. Tetrahedron Lett. 2001, 42, 4037.

6. Maillet, C.; Praveen, T.; Janvier, P.; Minguet, S.; Evain, M.; Saluzzo, C.; Tommasino, M. L.; Bujoli, B. J. Org. Chem. 2002, 67, 8191.

7. Li, X.; Chen, W.; Hems, W.; King, F.; Xiao, J. Org. Lett. 2003, 5, 4559. (b) Itsuno, S.; Tsuji, A.; Takahashi, M. Tetrahedron Lett. 2003, 44, 3825.

8. Liu, P. N.; Gu, P. M.; Wang, F.; Tu, Y. Q. Org. Lett. 2004, 6, 169. (b) Brethon, A.; Moreau J. J. E.; Wong Chi Man, M. Tetrahedron: Asymmetry 2004, 15, 495.

9. Reviews: G. Pozzi, G.; Shepperson, I. Coord. Chem. Rev. 2003, 242, 115. (b) Sinou, D. in Handbook of Fluorous Chemistry; Gladysz, J. A.; Curran, D.; Horváth, I. T. Eds.; WileyVCH: Weinheim, 2004; p 306. (c) Takeuchi, S.; Nakamura, Y. ibid. p 316. (d) Fache, F. New J. Chem. 2004, 1277.

10. Maillard, D.; Nguefack, C.; Pozzi, G.; Quici, S.; Valadé, B.; Sinou, D. Tetrahedron: Asymmetry 2000, 11, 2881. (b) Maillard, D.; Pozzi, G.; Quici, S.; Sinou, D. Tetrahedron 2002, 58, 3971. (c) Bayardon, J.; Sinou, D. Tetrahedron Lett. 2003, 44, 1449. (d) Bayardon, J.; Sinou, D. J. Org. Chem. 2004, 69, 3121. (e) Bayardon, J.; Sinou, D.; Holczknecht, O.; Mercs, L.; Pozzi, G. Tetrahedron: Asymmetry 2005, 16, 2319.

11. Bayardon, J.; Sinou, D. Synthesis 2005, 425.

12. Corey, E. J.; Lee, D.-H.; Sarshar, S. Tetrahedron: Asymmetry 1995, 6, 3.

13. Denmark, S. E.; Su, X.; Nishigaichi, Y.; Coe, D. M.; Wong, K.-T.; Winter, S. B. D.; Choi, J. Y. J. Org. Chem. 1999, 64, 1958.

14. Maillard, D.; Pozzi, G.; Sinou, D. Eur. J. Org. Chem. 2002, 269.

15. Itsuno, S.; Takahashi, M.; Tsuji, A. Macromol. Symp. 2004, 217, 191. 